\title{
Ecological response to collapse of the biological pump following the mass extinction at the Cretaceous-Paleogene boundary
}

\author{
Johan Vellekoop ${ }^{1,2, *}$, Lineke Woelders ${ }^{2, *}$, Sanem Açikalin $^{3}$, Jan Smit $^{4}$, Bas van de Schootbrugge ${ }^{1}$, Ismail Ö. Yilmaz ${ }^{5,6}$, \\ Henk Brinkhuis ${ }^{1,7}$, and Robert P. Speijer ${ }^{2}$ \\ ${ }^{1}$ Marine Palynology, Laboratory of Palaeobotany and Palynology, Faculty of Geosciences, Utrecht University, \\ Utrecht, $3584 \mathrm{CD}$, the Netherlands \\ ${ }^{2}$ Division of Geology, Department of Earth and Environmental Sciences, KU Leuven, Leuven-Heverlee, \\ 3001, Belgium \\ ${ }^{3}$ School of Civil Engineering and Geosciences, Newcastle University, NE1 7RU, Newcastle upon Tyne, UK \\ ${ }^{4}$ Department of Sedimentology and Marine Geology, Faculty of Earth and Life Science, Vrije Universiteit Amsterdam, \\ Amsterdam, 1018HV, the Netherlands \\ ${ }^{5}$ Department of Geological Engineering, Middle East Technical University, Ankara, Turkey \\ ${ }^{6}$ Department of Geological Sciences, University of Texas at Austin, Austin, TX 78712, USA \\ ${ }^{7}$ Royal Netherlands Institute for Sea Research (NIOZ), Landsdiep 4, 't Horntje, Texel, 1797 SZ, the Netherlands \\ *These authors contributed equally to this work.
}

Correspondence to: Johan Vellekoop (johan.vellekoop@kuleuven.be)

Received: 30 June 2016 - Discussion started: 3 August 2016

Revised: 16 December 2016 - Accepted: 26 January 2017 - Published: 27 February 2017

\begin{abstract}
It is commonly accepted that the mass extinction associated with the Cretaceous-Paleogene (K-Pg) boundary $(\sim 66 \mathrm{Ma})$ is related to the environmental effects of a large extraterrestrial impact. The biological and oceanographic consequences of the mass extinction are, however, still poorly understood. According to the "Living Ocean" model, the biological crisis at the $\mathrm{K}-\mathrm{Pg}$ boundary resulted in a long-term reduction of export productivity in the early Paleocene. Here, we combine organic-walled dinoflagellate cyst (dinocyst) and benthic foraminiferal analyses to provide new insights into changes in the coupling of pelagic and benthic ecosystems. To this end, we perform dinocyst and benthic foraminiferal analyses on the recently discovered Tethyan $\mathrm{K}-\mathrm{Pg}$ boundary section at Okçular, Turkey, and compare the results with other $\mathrm{K}-\mathrm{Pg}$ boundary sites in the Tethys. The post-impact dominance of epibenthic morphotypes and an increase of inferred heterotrophic dinocysts in the early Paleocene at Okçular are consistent with published records from other western Tethyan sites. Together, these records indicate that during the early Paleocene more nutrients remained available for the Tethyan planktonic community, whereas benthic communities were deprived of food.
\end{abstract}

Hence, in the post-impact phase the reduction of export productivity likely resulted in enhanced recycling of nutrients in the upper part of the water column, all along the western Tethyan margins.

\section{Introduction}

It is now commonly accepted that the Cretaceous-Paleogene (K-Pg) boundary ( $\sim 66 \mathrm{Ma})$ mass extinction was associated with the impact of a large extraterrestrial body at Chicxulub, Yucatan, Mexico. The short- and long-term environmental implications of this impact resulted in the extinction of a large number of biological clades (Sepkoski, 1996). Paleontological records indicate that approximately $50 \%$ of marine genera became extinct across the $\mathrm{K}-\mathrm{Pg}$ boundary. This episode thus represents one of the largest mass-extinction events in Earth history (Sepkoski, 1996; D'Hondt, 2005). Apart from short-term global environmental consequences, such as an initial "impact winter" phase (Alvarez et al., 1980; Vellekoop et al., 2014, 2016), the event also had major longterm biological consequences. The large-scale extinctions 
amongst primary producers caused a major restructuring of global food webs and carbon cycling (D'Hondt, 2005; Coxall et al., 2006). Moreover, a collapse in the oceanic stable carbon isotope gradient between surface and bottom waters persisted for up to a few million years (Hsü and McKenzie, 1985; Zachos et al., 1989; D’Hondt et al., 1998). Initially, the "Strangelove Ocean" hypothesis was invoked to explain this collapse, suggesting that primary productivity sharply decreased or ceased immediately after the K-Pg boundary as a consequence of the extinction of primary producers (e.g., Hsü and McKenzie, 1985).

However, modeling the carbon isotope gradient response to the extinctions suggests that carbon burial had to continue nearly unabated to prevent the carbon isotopic signature of the global ocean from drifting towards that of the weathering input (Kump, 1991). In addition, both the persistence of certain primary producers, such as dinoflagellates (e.g., Brinkhuis and Zachariasse, 1988), as well as the survival of benthic foraminifera (e.g., Culver, 2003) argue against prolonged cessation of primary productivity in the global oceans. Integration of neritic and deep-sea planktic and benthic foraminiferal carbon isotopic records suggests that the breakdown of this gradient reflects a global collapse of export productivity, i.e., the fraction of organic carbon that sinks from the photic zone to the deep ocean via the biological pump (Kump, 1991; D'Hondt et al., 1998; D'Hondt, 2005; Hilting et al., 2008; Hain et al., 2014; Esmeray-Senlet et al., 2015), rather than the shutdown of primary productivity. This conceptual model is generally referred to as the "Living Ocean" model (D'Hondt and Zachos, 1998; D'Hondt et al., 1998; D'Hondt, 2005). According to the Living Ocean model, total biological productivity recovered rapidly after the extinction event, but the total global export productivity from the photic zone was reduced for hundreds of thousands of years (D'Hondt et al., 1998; D'Hondt, 2005; Birch et al., 2016). Although there has been considerable debate on this possible collapse of the biological pump following the K-Pg boundary mass extinction (e.g., Alegret and Thomas, 2009; Hull et al., 2011), most recent studies are in agreement that global, post-K-Pg export productivity was reduced to some extent (e.g., Esmerey-Senlet et al., 2015; Birch et al., 2016). Current discussions are mostly related to the severity of the reduction of export productivity or the geographical differences (i.e., the "heterogeneity") of the oceans. In particular the records from the Pacific open ocean could, potentially, be explained as showing no reduction of the biological pump (e.g., Alegret et al., 2012; Hull et al., 2011), while sites from the Tethys Ocean, Atlantic Ocean, Southern Ocean, and Indian Ocean show convincing evidence for a collapse of a biological pump at the K-Pg boundary (e.g., Thomas, 1990; Olsson et al., 1996; Hull et al., 2011; Alegret et al., 2012).

The inferred reduction in the organic flux to deep waters recorded at most sites might be a consequence of the ecosystem reorganization that resulted from the mass extinction. Variations in species assemblages of pelagic communities can lead to large changes in the rates of particulate export (e.g., Buesseler, 1998; Stemmann and Boss, 2012). A general reduction of the number of pelagic grazers (such as macrozooplankton) or a shift in dominance from grazers that create fecal pellets (e.g., fish) to grazers that do not produce fecal pellets (e.g., dinoflagellates) could have greatly reduced the packaging of biomass into large particles sinking to the deep ocean (D'Hondt et al., 1998; D'Hondt, 2005). This is exemplified by the record at Gubbio, Italy, which indicates an abrupt decline of fish stocks at the K-Pg boundary, remaining depressed for millions of years in the western Tethys (Sibert et al., 2014).

Additionally, the replacement of large tests of Cretaceous planktic foraminifera and calcareous nanoplankton by smaller early Paleocene forms (e.g., Bernaola and Monechi, 2007; Molina, 2015) might have reduced biomineral ballasting (Armstrong et al., 2002) during the early Paleocene, resulting in a further reduction of the carbon flux to the ocean floor (Coxall et al., 2006).

Although numerous studies have been performed to seek physical evidence for the K-Pg boundary impact, the resulting millennial-scale biotic responses are still poorly understood. Some of the most intensely studied microfossil groups used in paleoenvironmental reconstructions, such as planktic foraminifera and calcareous nanoplankton, experienced major extinctions and subsequent radiations (e.g., Smit, 1982; Huber et al., 2002; Coxall et al., 2006; Molina, 2015; Schueth et al., 2015), hampering biota-based environmental reconstructions across the K-Pg boundary interval. In contrast, benthic foraminifera and organic-cyst-producing dinoflagellates are much better suited, as they show no significant extinction above background levels at the end of the Cretaceous (Brinkhuis and Zachariasse, 1988; Culver, 2003).

A few high-resolution K-Pg boundary benthic foraminiferal and organic-walled dinoflagellate cysts (dinocyst) records have been published, particularly from the southern and western shallow margins of the Tethys Ocean, for example from Tunisia, Israel, Egypt, Spain, and Morocco (Brinkhuis and Zachariasse, 1988; Eshet et al., 1992; Coccioni and Galeotti, 1994; Speijer and van der Zwaan, 1996; Brinkhuis et al., 1998; Peryt et al., 2002; Alegret et al., 2003; Slimani et al., 2010; Vellekoop et al., 2015) (Fig. 1). These records thus potentially provide a comprehensive, Tethys-wide portrayal of the changes in pelagic-benthic-coupling across the $\mathrm{K}-\mathrm{Pg}$ boundary. The benthic foraminiferal and dinocyst records from the southern margin of the Tethys do reveal indications for major, short-term oceanographic changes in, e.g., temperature, redox, and trophic conditions across the K-Pg boundary (e.g., Brinkhuis and Zachariasse, 1988; Speijer and van der Zwaan, 1996; Brinkhuis et al., 1998). Especially quantitative benthic foraminiferal records show a strong response to the impact, generally portraying an abrupt benthic community impoverishment across the boundary. At many of these K-Pg boundary sites, after an initial short-lived prolifer- 


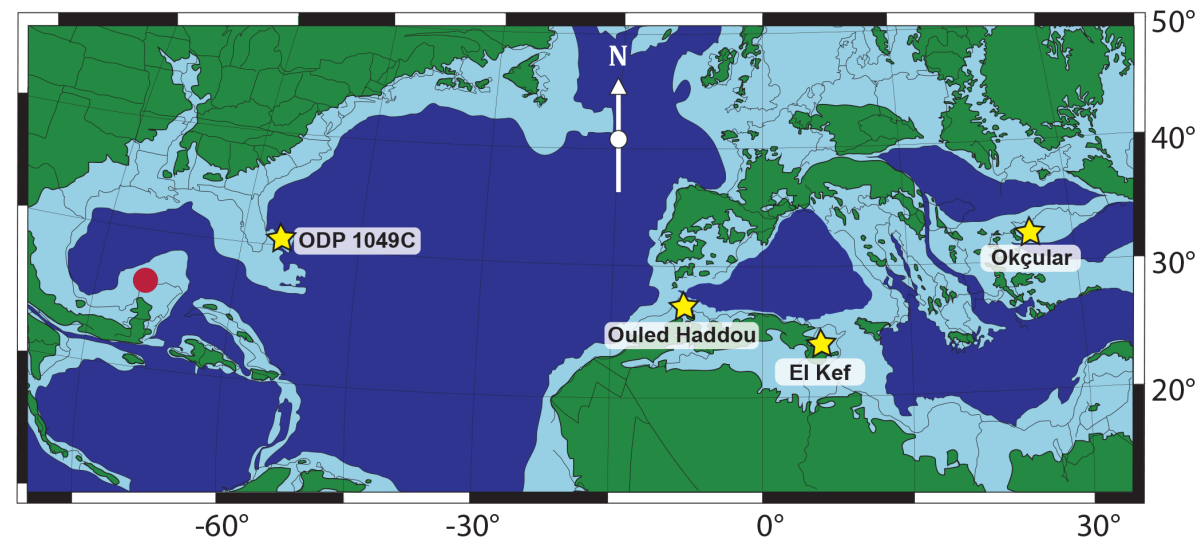

Figure 1. Reconstruction of the late Cretaceous-early Paleogene paleogeography of the North Atlantic and Mediterranean regions, after Scotese (2004) and Scotese and Dreher (2012). The four sites discussed are indicated: Okçular section, Turkey (Açikalin et al., 2015; this study); El Kef, Tunisia (Brinkhuis and Zachariasse, 1988; Speijer and van der Zwaan, 1996; Brinkhuis et al., 1998); Ouled Haddou, Morocco (Slimani et al., 2010); and ODP Hole 1049C (Blake Nose; Alegret and Thomas, 2004). The red dot marks the Chicxulub impact crater.

ation of endobenthic forms (e.g., Coccioni and Galeotti, 1994; Alegret et al., 2015), epibenthic forms dominate the post-impact "disaster" phase (Culver, 2003). Since in general endobenthic forms are considered indicative of a high flux of organic matter to the sea floor and/or relatively low oxygen conditions, and epibenthic forms are generally more common in oligotrophic open marine environments (e.g., Corliss, 1985; Peryt et al., 2002; Jorissen et al., 2007; Woelders and Speijer, 2015), the post-impact abundance of epibenthic forms is often explained as food starvation at the sea floor (Culver, 2003). Following this disaster phase, most benthic foraminiferal records show a relatively long recovery phase, with endobenthic forms gradually returning as diversity starts to increase again (Alegret et al., 2003; Culver, 2003) and endobenthic microhabitats diversify (Speijer and van der Zwaan, 1996).

Although combining quantitative dinocyst and benthic foraminifera analyses could provide crucial insight into changes in pelagic-benthic-coupling (e.g., Guasti et al., 2005), perhaps surprisingly, no such attempts have been made for the K-Pg boundary interval so far. Earlier studies discussed either benthic foraminiferal or dinoflagellate response to the K-Pg boundary, each without making an attempt to combine the results of these studies into a comprehensive, integrated ocean-wide characterization of ecological patterns observed across the boundary. In addition, although the southern margins of the western Tethys provided a fair number of high-resolution records spanning the $\mathrm{K}-\mathrm{Pg}$ boundary, no such high-resolution records yet exist from the northeastern margins of the western Tethys. To be able to provide a comprehensive, (western) Tethys-wide portrayal of the surface and bottom water ecological changes across the $\mathrm{K}-\mathrm{Pg}$ boundary and the coupling between pelagic and benthic systems, additional dinocyst and benthic foraminiferal records need to be generated from the northeastern margin of the western Tethys.

The Mudurnu-Göynük basin in the central Sakarya region, northwestern Turkey, provides new opportunities for high-resolution $\mathrm{K}-\mathrm{Pg}$ boundary benthic foraminiferal and dinocyst records from the northern margin of the Tethys. Recently, well-preserved outcrops of ancient continental margin deposits spanning the K-Pg boundary have been discovered in this basin (Açikalin et al., 2015). These outcrops include, amongst others, the Okçular section. Here, an integration of dinocyst and benthic foraminifera records of this biostratigraphically well-constrained K-Pg boundary transition is used to provide new insights into changes in, and the relationship between, planktic and benthic communities.

Linking these records to both the previously generated bulk-carbonate carbon isotope record of this section (Açikalin et al., 2015) and to other benthic foraminiferal and palynological records in the Tethys enables a supra-regional portrayal of the K-Pg boundary pelagic crisis and the biological changes caused by the collapse of export productivity. This integrated approach enables an evaluation of the paleoecological and paleoceanographic consequences of the early Danian Living Ocean condition.

\section{Geological setting and age assessment}

The Okçular section is located in the Mudurnu-Göynük basin (northwestern Turkey; Fig. 1). In this basin, the KPg boundary interval is represented by the Tarakli Formation (Saner, 1980; Altiner et al., 1991; Açikalin et al., 2015). In the eastern part of the basin, the upper Maastrichtian is characterized by an intercalation of mudstones and turbidites, whereas in the western part of the basin the turbidites are absent. The $\mathrm{K}-\mathrm{Pg}$ boundary is marked by a reddish ejecta layer at the base of a $15-20 \mathrm{~cm}$ thick boundary 
clay layer. Throughout the basin, the lower $30-50 \mathrm{~m}$ of the Danian is characterized by a rhythmic alternation of finegrained limestones and carbonate-rich mudstones (Açikalin et al., 2015). During the latest Cretaceous to early Paleocene this basin was characterized by mixed siliciclastic-carbonate sedimentation in an outer neritic to upper bathyal environment (Açikalin et al., 2015).

The Okçular section has been analyzed for siderophile trace elements, including Ir and other platinum group elements (PGEs), bulk stable carbon isotopes, planktic foraminifera, calcareous nannofossils, and dinocysts. Based on these results, a detailed stratigraphic framework was outlined (Açikalin et al., 2015), allowing a confident age assessment of the boundary interval. The age model shows that the section contains a chronostratigraphically complete $\mathrm{K}-$ $\mathrm{Pg}$ boundary interval. The studied interval ranges from the top part of the Maastrichtian A. mayaroensis Zone up to the basal part of the Danian planktic foraminiferal Zone P1b and covers globally occurring first occurrences (FO) of dinocyst marker taxa such as Senoniasphaera inornata, Damassadinium californicum, and Carpatela cornuta.

\section{Materials and methods}

\subsection{Sampling}

High-resolution (centimeter-scale) sample sets were acquired during two field campaigns, in 2010 and in 2011. For more detail on these sampling campaigns, see Açikalin et al. (2015). The samples were split for micropaleontological and palynological analyses.

\subsection{Foraminiferal analysis}

Twenty-seven samples were processed at KU Leuven for foraminiferal studies following standard micropaleontological procedures. Of these, 20 samples were used for quantitative benthic foraminiferal analyses (Fig. 2). Rock samples were dried in an oven at $60^{\circ} \mathrm{C}$ for at least $24 \mathrm{~h}$. Depending on sample size, 4 to $60 \mathrm{~g}$ of dry rock was soaked in a soda $\left(\mathrm{Na}_{2} \mathrm{CO}_{3}\right)$ solution $\left(50 \mathrm{~g} \mathrm{~L}^{-1}\right)$. After disintegration, samples were washed over $2 \mathrm{~mm}$ and $63 \mu \mathrm{m}$ sieves. If necessary, the tenside Rewoquat was used to clean the residues and the procedure was repeated. Clean residues were dry-sieved into three fractions: $63-125,125-630$, and $>630 \mu \mathrm{m}$. In order to enable a direct comparison with the benthic foraminiferal record of the K-Pg boundary GSSP (Global Boundary Stratotype Section and Point) of El Kef (Tunisia), we used the same size fraction $(>125 \mu \mathrm{m})$ for Okçular as for El Kef (Speijer and van der Zwaan, 1996). Note that El Kef holds the GSSP of the base of the Danian (Molina et al., 2006) and is thus of particular importance with respect to correlation and comparison of the K-Pg boundary. Representative aliquots of the $>125 \mu \mathrm{m}$ fraction were obtained, containing at least 300 benthic foraminiferal specimens. Picked specimens from this size fraction were permanently stored in Plummer slides. Benthic foraminifera were identified using the taxonomy of Cushman (1946, 1951), Kellough (1965), Aubert and Berggren (1976), Berggren and Aubert (1975), and Speijer (1994).

Benthic foraminifera are commonly used as indicators for bottom water oxygenation and trophic conditions (e.g., Jorissen et al., 2007). Here, the benthic foraminiferal accumulation rate (BFAR; number of foraminifera per $\mathrm{cm}^{2}$ per kyr; see Text S2 in the Supplement for details on the estimation of BFAR) was calculated as a semi-quantitative proxy for paleoproductivity (Jorissen et al., 2007 and references therein). In addition, the percentage of endobenthic morphotypes was calculated using the assumed microhabitat preferences inferred from benthic foraminiferal morphotype analysis (e.g., Corliss, 1985; Corliss and Chen, 1988; Alegret et al., 2003; Woelders and Speijer, 2015). In general, endobenthic forms are considered indicative of a high flux of organic matter to the sea floor and/or relatively low oxygen conditions, while abundance of epibenthic forms is considered characteristic for more oligotrophic open marine environments (Jorissen et al., 1995; Peryt, 2004; Jorissen et al., 2007). Furthermore, the bi- and triserial endobenthic forms are particularly indicative of high food supply and low oxygenation (e.g., Bernhard, 1986; Corliss and Chen, 1988; Jorissen et al., 2007). Therefore in this study, the percentage of endobenthic forms was calculated for each sample, as well as the percentage bi/triserial benthic taxa, to unravel food supply and oxygenation patterns.

It should, however, be noted that assuming such an analogue with modern fauna has limitations and shortcomings. For instance, the percentage of endobenthics based on morphotypes and using bi-/triserials as an indicator for hypoxia and high food supply is not universally applicable (Buzas et al., 1993; Jorissen et al., 2007, and references therein).

\subsection{Palynological analysis}

In this study, the palynological data from Açikalin et al. (2015) were analyzed and interpreted. In addition, two additional samples were analyzed (OK 1.5 and OK 6) to increase the resolution of the dataset and two samples of the Açikalin et al. (2015) dataset were re-counted (OK 2.5 and OK 250; see Dataset 2 in the Supplement). Quantitative slides of the $15-250 \mu \mathrm{m}$ fraction were used. All slides are stored in the collection of the Laboratory of Palaeobotany and Palynology, Utrecht University, the Netherlands.

To identify major changes in the dinocyst record, morphologically closely related taxa were grouped into complexes using a similar approach to Schiøler et al. (1997), Sluijs and Brinkhuis (2009), and Machalski et al. (2016). In our study, the following morphological complexes were established: (1) the Spiniferites complex, combining all species of Spiniferites and the morphologically similar genus Achomopshaera; (2) Manumiella spp., grouping all species of Man- 


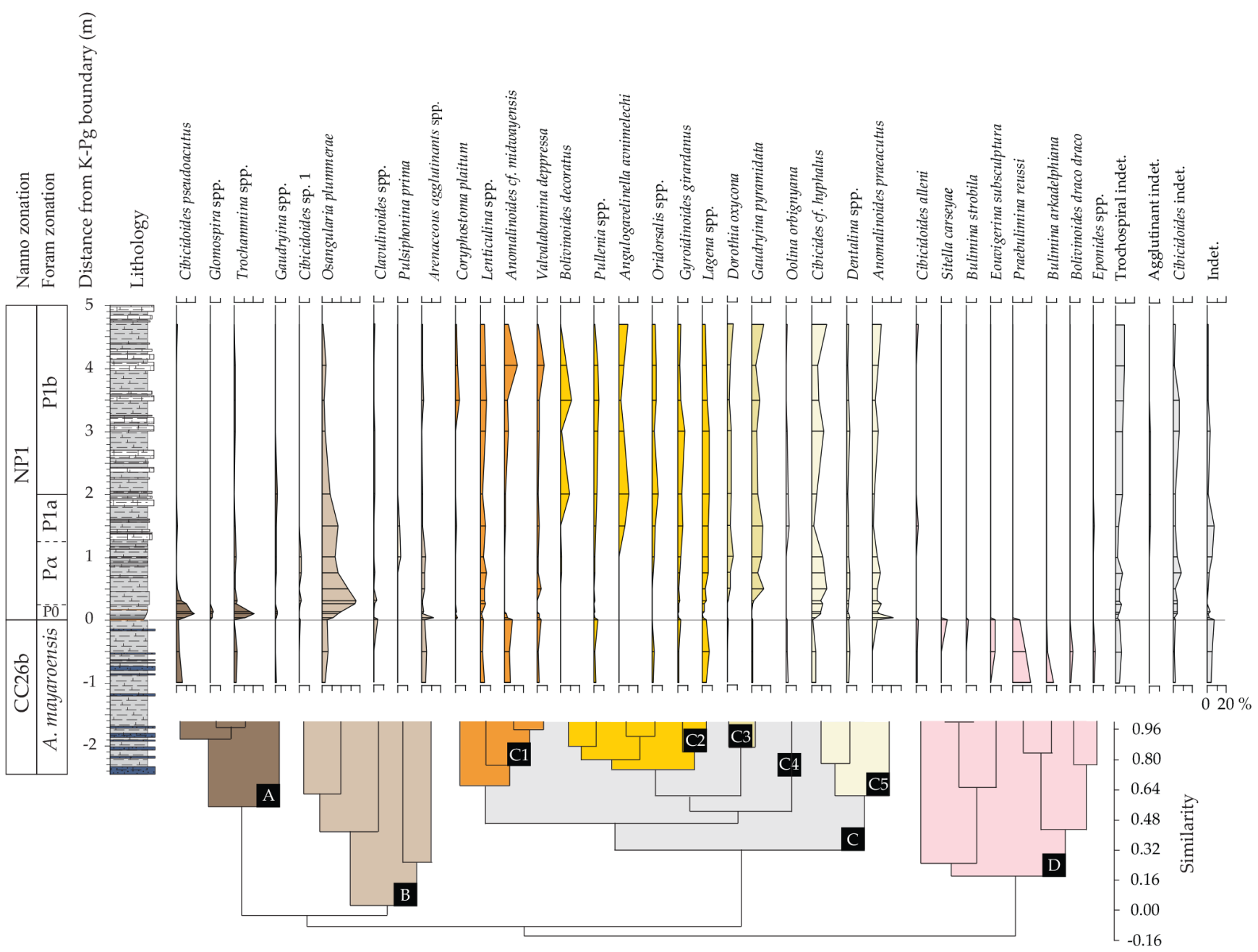

Figure 2. The benthic foraminiferal record (>125 $\mu \mathrm{m})$ of the Okçular section. The biostratigraphy is from Açikalin et al. (2015). The cluster analysis on the benthic foraminiferal data using paired group (UPGMA) correlation distance allows the identification of four main clusters, A-D, of benthic foraminiferal taxa.

umiella; (3) hexaperidinioids, lumping all other peridinioid cysts with a hexaform archeopyle; and (4) other dinocysts, which include all other dinocyst taxa and unidentifiable dinocysts (Fig. 3).

Of these different dinocyst groups, previous studies have shown that in the Tethys the hexaperidinioids in particular show strong variations across the K-Pg boundary (Brinkhuis et al., 1998; Vellekoop et al., 2015). Based on statistical correlations between palynological records and other paleoproxies, it has been suggested that this inferred heterotrophic group flourished best under high-nutrient conditions in the photic zone (Eshet et al., 1994; Brinkhuis et al,. 1998; Sluijs and Brinkhuis, 2009). Therefore in this study, abundances of hexaperidinioids are considered indicative of nutrient availability in the photic zone (see Fig. S1 and Text S1 in the Supplement for a more detailed discussion on this matter).

\subsection{Statistical analysis}

To assess changes in diversity of benthic foraminifera and dinocysts across the studied interval, the Shannon diversity index $(H)$, the species richness per sample $(S)$, the number of specimens observed per sample $(N)$, and the Berger-Parker index were calculated for both biological groups, following Hayek and Buzas (2013) (Fig. 4). In addition, in order to recognize the main faunal associations within the benthic foraminiferal data, a cluster analysis was performed using paired group (UPGMA) correlation distance.

Q-mode non-metric multidimensional scaling (NM-MDS) was performed on the benthic foraminiferal sample compositions to assess patterns in assemblage response to $\mathrm{K}-\mathrm{Pg}$ boundary perturbations. Since taxa may not have a linear response to environmental changes across the K-Pg boundary, Q-mode NM-MDS is preferred over PCA and CCA (Ramette, 2007). 


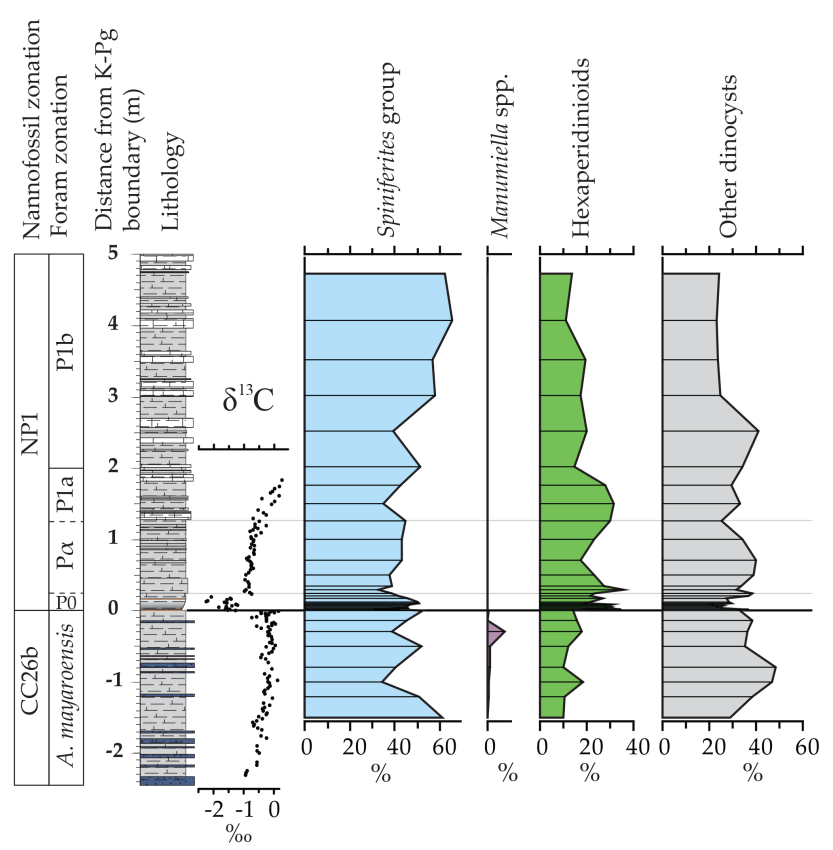

Figure 3. The organic-walled dinoflagellate cyst record of the Okçular section. The biostratigraphy and bulk carbonate stable carbon isotope records are from Açikalin et al. (2015). The four main dinocyst complexes are indicated.

\section{Results}

\subsection{Benthic foraminifera}

The benthic foraminiferal record of the Okçular section is characterized by a distinct turnover across the $\mathrm{K}-\mathrm{Pg}$ boundary (Figs. 2, 4, 5, 6). Of the common taxa, 8 out of 30 $(\sim 27 \%)$ disappear across the K-Pg boundary. After the KPg boundary crisis, three new taxa appear. The estimated BFAR shows a major decrease across the boundary (Fig. 5). For the foraminiferal counts and illustrations of common forms, see Dataset S1 and Figs. S2, S3.

The cluster analysis allows the identification of four main clusters of benthic foraminiferal taxa, clusters $A$ to $\mathrm{D}$ (Fig. 2). Cluster $\mathrm{C}$ is relatively large and can be subdivided into five subclusters. Based on the succession of benthic faunal assemblages, characterized by strong changes in the Shannon diversity index $(H)$, four intervals can be recognized in the benthic foraminiferal record of the Okçular section (Figs. 4, 6).

The first interval comprises the uppermost Maastrichtian and is characterized by relatively high diversity, dominated by the taxa in cluster D. In this assemblage, the bi-/triserial benthic taxa are relatively abundant (22-28\%), with characteristic taxa such as Bulimina arkadelphiana, Eouvigerina subsculptura and Praebulimina reussi. About 50-60\% of the assemblage consists of inferred endobenthic taxa. The $\mathrm{K}-$ $\mathrm{Pg}$ boundary marks an abrupt benthic community impover- ishment and the decimation of the taxa in cluster D. Above the boundary, the bi-/triserial benthic taxa virtually disappear from the record (mostly below $<0.5 \%$ ).

The second interval, characterized by low diversity, comprises the lowermost Danian, approximately corresponding to planktic foraminiferal Zone P0. In this interval epibenthic forms are most abundant (70-90\%). It is dominated by the taxa of cluster A, encompassing successive peak occurrences of the taxa Anomalinoides praeacutus, Trochammina spp., and Cibicidoides pseudoacutus.

The third interval covers the part of the succession approximately correlative to planktic foraminiferal Zone $\mathrm{P} \alpha$. This interval is characterized by a recovery of diversity, although the diversity is still lower than that of the top Maastrichtian assemblage. The abundance of taxa in cluster A slowly decreases and taxa in cluster B, mainly represented by Osangularia plummerae and Cibicidoides sp., become abundant. Endobenthic forms recover and make up 30-40\% of the total assemblage.

The fourth interval starts in the interval correlative to Zone P1a. Here, the benthic community has recovered as the diversity has stabilized and is almost similar to pre-impact values. This interval is characterized by taxa in cluster C, a typical Paleocene Midway-type fauna (Berggren and Aubert, 1975), with representatives such as Anomalinoides praeacutus, Coryphostoma midwayensis, Cibicidoides alleni, and Osangularia plummerae.

\subsection{Palynology}

Palynological samples from the Okçular site yield abundant palynomorphs dominated by dinocysts and with minor contributions of acritarchs, prasinophytes, organic foraminiferal linings, and terrestrial palynomorphs (Dataset S2). The dinocyst associations of the Mudurnu-Göynük basin are quite diverse, including components characteristic of both the Tethyan and Boreal realms (Açikalin et al., 2015). As expected, the dinocyst record does not show major changes in diversity across the $\mathrm{K}-\mathrm{Pg}$ boundary (Fig. 4). There is a steady decrease in dinocyst diversity from planktic foraminiferal Zone P1a upwards, probably a long-term change not related to the impact. The estimated dinocyst accumulation rate (DAR; number of preserved cysts per $\mathrm{cm}^{2}$ per kyr; see Text S2 in the Supplement for details on the estimation of the DAR) shows no major changes across the K-Pg boundary.

Throughout the palynological record, the Spiniferites complex is consistently the most dominant morphogroup, in general comprising $40-50 \%$ of the total assemblage (Fig. 3). Similar to other K-Pg boundary sites worldwide (Habib and Saeedi, 2007), Manumiella spp. show an episode of higher relative abundance near the top of the Maastrichtian some $30-40 \mathrm{~cm}$ below the $\mathrm{K}-\mathrm{Pg}$ boundary. Hexaperidinioids generally make up a relatively small component of the Maastrichtian assemblage (3-17\%) but show a strong increase across the $\mathrm{K}-\mathrm{Pg}$ boundary. In the boundary clay layer, cor- 


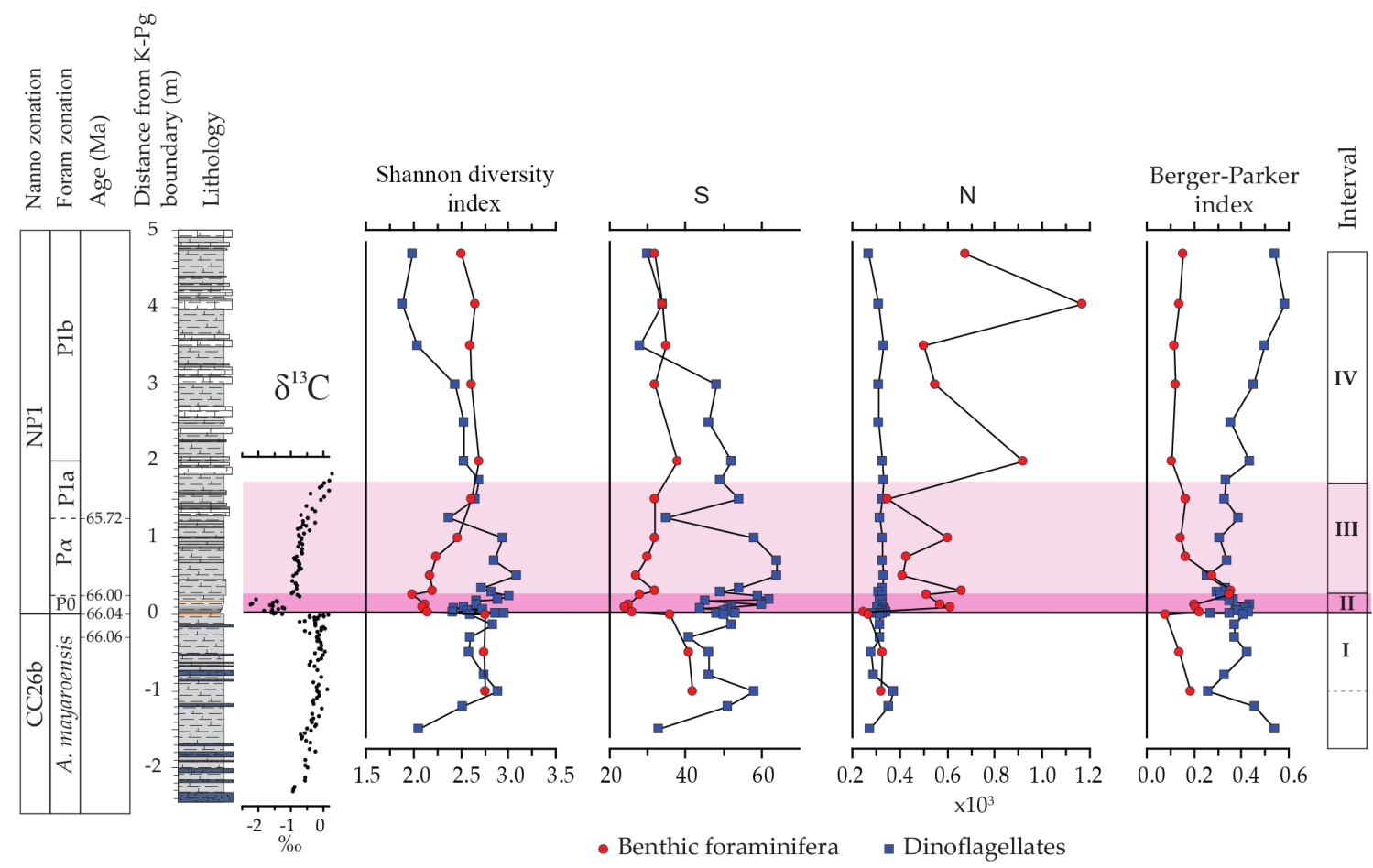

Figure 4. Diversity indices on the benthic foraminiferal and dinocyst records of the Okçular section with the Shannon diversity index $(H)$, the species richness per sample $(S)$, the number of specimen observed per sample $(N)$, and the Berger-Parker index. As the bulk stable carbon isotope record and the Shannon diversity index of the benthic foraminiferal record show similar trends, the combination of these records can be used to subdivide the K-Pg boundary transition into four intervals: I, the Maastrichtian, i.e., "pre-impact" interval; II, the post-impact interval, representing the "disaster" phase; III, a recovery interval; and IV, the early Paleocene post-recovery interval. The division criteria are explained in the text.

relative to planktic foraminiferal Zone $\mathrm{P} 0$, this group increases to $35 \%$ of the assemblage. In the peak intervals, the hexaperidinioids are mostly represented by representatives of the genera Senegalinium and Cerodinium. After an initial drop in relative abundance in the upper half of Zone P0, this group reaches a second maximum $(\sim 35 \%)$ at the base of Zone $\mathrm{P} \alpha$ and remains relatively abundant (15-30\%) up to Zone P1a. After this, the hexaperidinioids gradually decrease towards the top of the studied interval. The "other dinocysts" group - with representatives such as Areoligera spp., Impagidinium spp., Hystrichosphaeridium tubiferum, Operculodinium centrocarpum, and Palynodinium grallator - generally makes up $25-50 \%$ of the assemblage.

\section{Discussion}

\subsection{Tethyan benthic foraminiferal turnover sequence}

The major turnover in the benthic community at Okçular is largely comparable with the previously published benthic foraminiferal record (size fraction $>125 \mu \mathrm{m}$ ) of the $\mathrm{K}$ Pg boundary GSSP of El Kef (Figs. 7, 8; Speijer and Van der Zwaan, 1996). In addition, other benthic foraminiferal records from the margins of the Tethys also show a strong similarity to the Okçular and El Kef records, including studies that use the $>63 \mu \mathrm{m}$ size fraction (Alegret et al., 2003; Culver, 2003, and references therein).

Although it is sometimes suggested that different size fractions cannot be directly compared because the different size fractions sometimes harbor different ecological information (Giusberti et al., 2016), intercomparison studies have shown that when comparing the $>125$ and $>63 \mu \mathrm{m}$ size fractions in benthic foraminiferal assemblages the overall patterns are generally robust (Ernst et al., 2006). The fact that $>63$ and $>125 \mu \mathrm{m} \mathrm{K-Pg}$ boundary benthic foraminiferal records from different Tethys-margin sites (e.g., Speijer and Van der Zwaan, 1996; Peryt et al., 2002; Culver et al., 2003) show striking similarities, even though both the size fractions used ( $>63$ vs. $>125 \mu \mathrm{m}$ ) and specific taxa making up the foraminiferal assemblages differ among sites, confirms the observations by Ernst et al. (2006). Furthermore, even when it would be assumed that different size fractions are difficult to compare directly, the striking similarities between the Tethyan $>125$ and $>63 \mu \mathrm{m}$ size fraction K-Pg boundary benthic foraminiferal records provide compelling evidence for a strong disruption of the entire benthic community.

Tethyan middle neritic to middle bathyal K-Pg boundary successions generally show a sequence of (1) a typical high 


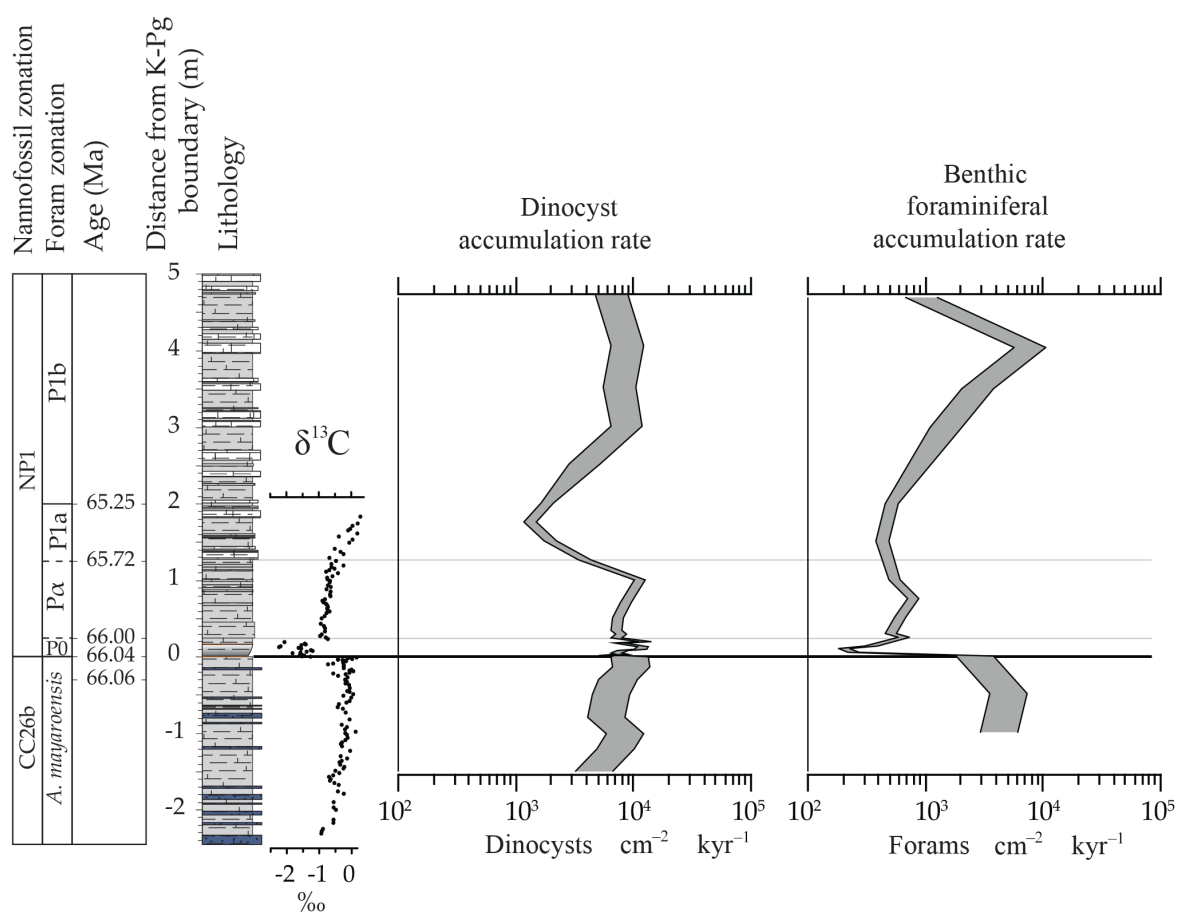

Figure 5. Estimated benthic foraminiferal accumulation rate (BFAR; number of foraminifera of the $>63 \mu \mathrm{m}$ size fraction per $\mathrm{cm}^{2}$ sea floor per kyr) and estimated dinocyst accumulation rate (DAR; number of preserved cysts per $\mathrm{cm}^{2}$ sea floor per kyr) of the Okçular section. Uncertainty in estimated accumulation rates, resulting from uncertainties in sediment densities and sedimentation rates, are indicated in grey, providing a range of estimated accumulation rates. For more detailed info on the calculation of the BFAR and DAR, see Text S2 of the Supplement.

diversity assemblage in the Maastrichtian; (2) a low diversity "disaster" assemblage directly after the K-Pg boundary impact, characterized by a short-lived bloom of endobenthic forms observed in several high-resolution records (e.g., Coccioni and Galeotti, 1994; Speijer and van der Zwaan, 1996), followed by a dominance of epibenthic forms; (3) a "recovery" assemblage, characterized by an increasing diversity and returning endobenthic forms; and (4) a new, high diversity assemblage, dominated by a Paleocene fauna, with both epi- and endobenthic forms equally represented.

Hence, based on this succession of benthic assemblages, which are characterized by strong changes in diversity $(H)$, the K-Pg boundary benthic foraminiferal records from the Tethys can be subdivided into four intervals (Figs. 2, 4-6). The intervals I to IV approximately correspond to the uppermost Maastrichtian, planktic foraminiferal Zone P0, subzones $\mathrm{P} \alpha-\mathrm{P} 1 \mathrm{a}$, and subzones $\mathrm{P} 1 \mathrm{a}-\mathrm{P} 1 \mathrm{~b}$, respectively. Therefore, this succession roughly follows the 5-fold sedimentological and planktic foraminiferal sequence of Smit and Romein (1985), in which unit 2 represents the ejecta layer and units 1, 3, 4 and 5 correspond to intervals I to IV in our study.

The sequence of benthic foraminiferal turnover in the Tethys is also well illustrated by a Q-mode NM-MDS
(Fig. 7). The Q-mode NM-MDS of the benthic foraminiferal sample compositions of the combined data from Okçular (this study) and El Kef (Speijer and van der Zwaan, 1996) demonstrates that although the assemblages differ between these localities on opposite margins of the Tethys, the responses of the benthic foraminiferal assemblages to the K-Pg boundary perturbations express very similar overall patterns across the K-Pg boundary. At both Okçular and El Kef, the benthic foraminiferal records show a rapid transition from a stable Maastrichtian assemblage to the earliest Danian disaster phase in Zone P0, followed by a gradual change back towards conditions similar to the Maastrichtian (marked by the return of Lazarus taxa). Therefore, both the succession of benthic faunal assemblages, including diversity indices, and Q-mode NM-MDS analysis provide powerful tools to allow the comparison of K-Pg boundary benthic foraminiferal records from different localities.

\subsection{Ecological responses to reduced export productivity}

\subsubsection{Okçular section}

The palynological benthic foraminiferal and bulk stable isotope records of the Okçular section show major changes across the K-Pg boundary interval (Figs. 2-7), portraying 


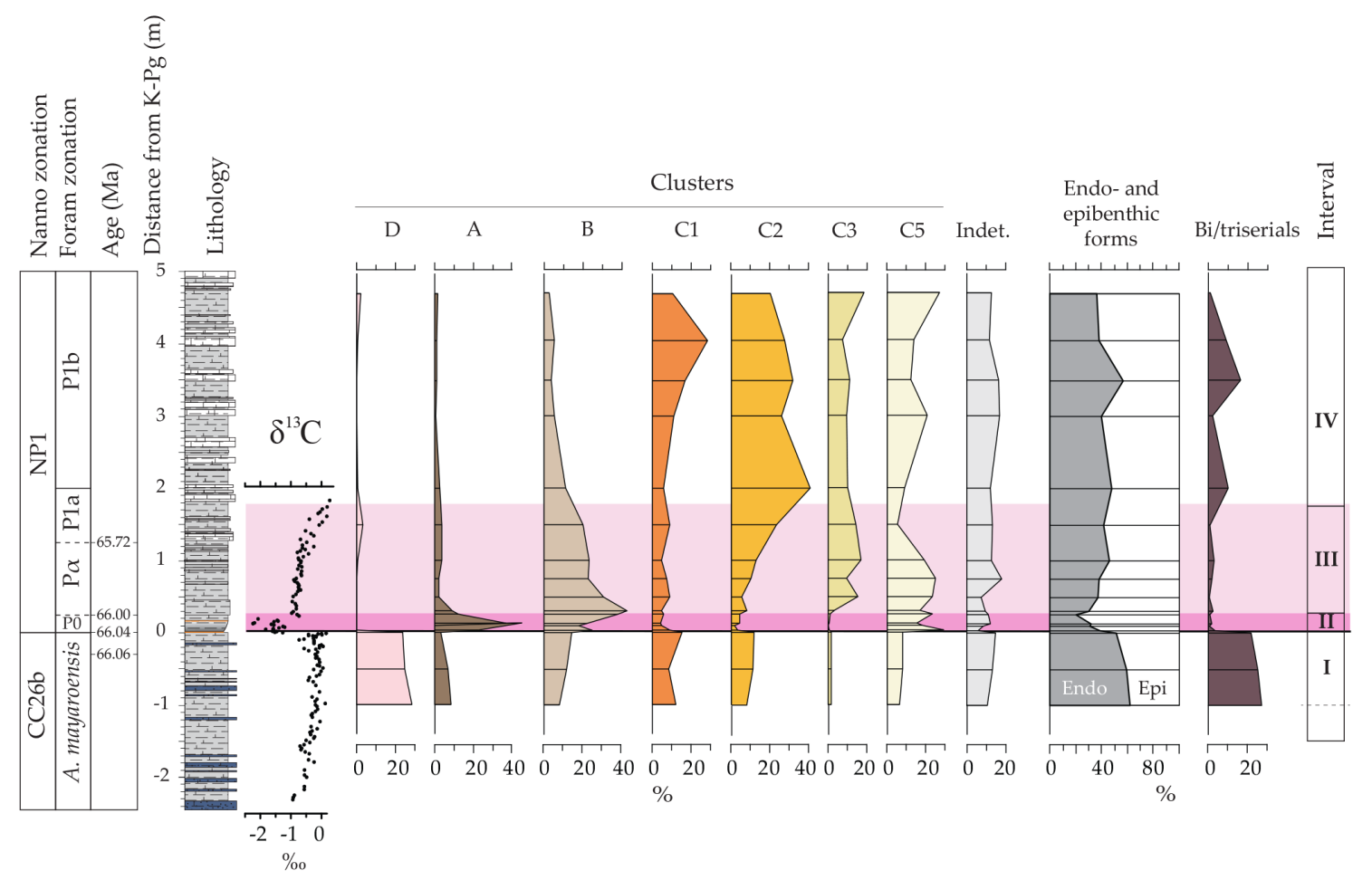

Figure 6. Relative abundances of the four main clusters of benthic foraminiferal taxa $(>125 \mu \mathrm{m})$, relative abundances of epibenthic and endobenthic forms, and relative abundance of bi-/triserial benthic taxa.

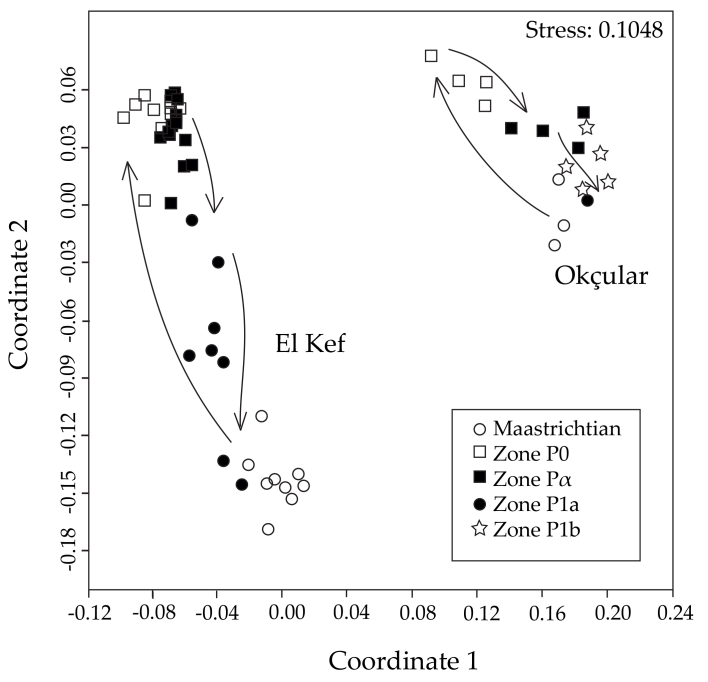

Figure 7. Q-mode non-metric multidimensional scaling (on all samples in the $>125 \mu \mathrm{m}$ size fraction benthic foraminiferal datasets of Okçular (this study) and El Kef (Speijer and van der Zwaan, 1996). After an abrupt transition from latest Maastrichtian pre-impact assemblages to disaster assemblages in Zone P0 and recovery assemblages in Zone $\mathrm{P} \alpha$, a gradual transition towards a new equilibrium post-recovery assemblage can be observed in subzones $\mathrm{P} 1 \mathrm{a}$ and $\mathrm{P} 1 \mathrm{~b}$. the biological crisis following the impact. Following the KPg boundary mass extinction, endobenthic forms strongly decrease, with bi-/triserial benthic taxa almost disappearing from the benthic community; simultaneously, the estimated BFAR shows a major fall (Fig. 5). This interval, approximately correlative to foraminiferal Zone $\mathrm{P} 0$, represents the disaster phase. The drop in bi-/triserial benthic taxa (Fig. 6) and decrease in BFAR (Fig. 5) point to a reduction in food supply to the benthic community, indicating that the transport of organic matter to the sea floor must have decreased. In the dinocyst community, however, hexaperidinioids show a strong increase in relative abundance during this phase (Figs. 3, 6,7), suggesting an increase in nutrient availability in the photic zone, while the DAR remains relatively stable across the K-Pg boundary (Fig. 5).

The decrease in benthic diversity and the high relative abundances of opportunistic Trochammina spp. and Cibicidoides pseudoacutus suggest that the benthic community experienced additional stress during Zone $\mathrm{P} 0$, besides food limitation (see Jorissen et al., 2007). If food limitation were the only factor involved, upper bathyal assemblages as observed at Okçular would be expected to become more similar to oligotrophic middle to lower bathyal assemblages. Instead, the opposite is true: the assemblage composition of the disaster phase is closer to neritic Midway-type assemblages.

It was previously suggested that the epibenthic taxon $\mathrm{Cibi}$ cidoides pseudoacutus could potentially be hypoxia resistant 
(Speijer and van der Zwaan, 1996). As a collapse of the biological pump should lead to enhanced remineralization of organic matter in the photic zone, it is indeed likely that the oxygen minimum zones expanded and shoaled, leading to oxygen stress on the sea floor. Although early Paleocene dysoxia at El Kef is supported by the ostracod record (Donze et al., 1982) and ichnofacies analyses (Rodriguez-Tovar et al., 2016), supporting (e.g., geochemical) evidence for dysoxia during the disaster phase at Okçular record is absent. Furthermore, an additional stressor for the benthic community during Zone P0 may be present. In contrast to calcareous nanoplankton, organic-walled cyst-producing dinoflagellates did not suffer extinctions and may have become a more important component in the early Paleocene phytoplankton community. Hence, besides the reduction of the amount of organic matter transported to the sea floor, the composition of food supplied by the photic zone likely changed significantly across the K-Pg boundary as well (D'Hondt, 2005), possibly presenting an additional stress factor for the benthic community (Speijer and van der Zwaan, 1996; Alegret and Thomas, 2009).

\subsubsection{Western Tethys}

The patterns in benthic foraminiferal and dinoflagellate response to the K-Pg boundary perturbations at Okçular appear to be characteristic for the continental margins of the western Tethyan realm. The benthic foraminiferal patterns are similar across different size fractions, suggesting that they are representative of the overall benthic communities. In Tunisia and Spain, where both benthic foraminiferal and dinoflagellate records are available, the earliest Danian is also characterized by a decrease in endobenthic foraminifera at the sea floor (Speijer and Van der Zwaan, 1996; Peryt et al., 2002; Alegret et al., 2003) and, simultaneously, blooms of hexaperidinioids in the water column (Brinkhuis et al., 1998; Vellekoop et al., 2015; Fig. 8). In the Ouled Haddou section, Morocco, in the westernmost Tethys (Fig. 1), the lowermost Danian is also characterized by a strong increase of the hexaperidinioid Senegalinium group, up to $30 \%$ of the assemblage (Slimani et al., 2010), that is very similar to the Okçular record (Fig. 8).

The K-Pg boundary dinocyst record of El Kef is strikingly similar to the one from the Okçular section, showing two distinct peaks in hexaperidinioids; one in Zone $\mathrm{P} 0$ and one at the basal part of Zone P $\alpha$. At El Kef, the initial post-impact dominance of hexaperidinioids is, however, less pronounced (Fig. 8). This difference in expression might be related to small differences in paleogeographic and paleoceanographic settings between sites.

In addition, some high-resolution benthic $\mathrm{K}-\mathrm{Pg}$ records in the Tethyan realm show a short-lived bloom of specific endobenthic foraminiferal taxa in the few centimeter directly above the K-Pg boundary, sometimes accompanied by other indicators of low oxygen levels (e.g., Coccioni and Gale- otti, 1994; Speijer and Van der Zwaan, 1996; Kaiho et al., 1999). This suggests that, at least locally, the sea floor was temporarily characterized by hypoxic conditions directly following the impact. This short-lived deoxygenation is possibly related to the mass mortality at the K-Pg boundary, resulting in a large, short-lived flux of organic matter to the sea floor (Coccioni and Galeotti, 1994). However, since export productivity was greatly reduced after the K-Pg boundary mass extinction, very little "new" organic matter reached the sea floor after the initial post-impact influx. Hence, after accumulated organic matter was remineralized, the benthic community starved, resulting in a transition to an epibenthicdominated benthic fauna similar to the post-impact fauna of the Okçular record.

The combined dinocyst records suggest that the early $\mathrm{Pa}$ leocene margins of the Tethys were characterized by an increase in nutrient availability in the photic zone, whereas coeval benthic foraminiferal records indicate a major decrease in nutrient supply to the sea floor. These changes in the benthic foraminiferal and dinocyst communities are likely caused by the major reduction of both the efficiency and strength of the biological pump (i.e., the fraction of primary production exported from the photic zone and the amount of organic matter transported down) in accordance with the Living Ocean model (D'Hondt and Zachos, 1998; D'Hondt et al., 1998; D'Hondt, 2005; Coxall et al., 2006). For a detailed explanation of the difference between biological pump efficiency and biological pump strength, see Hilting et al. (2008).

As bulk carbonate $\delta^{13} \mathrm{C}$ reflects the isotopic composition of the surface ocean, which is set by burial fractions and by the photosynthetic isotope effect (Kump, 1991; Hain et al., 2014), the excursion recorded in bulk $\delta^{13} \mathrm{C}$ records worldwide and the rapid collapse in surface to deep-ocean carbon isotope gradients likely reflect the reduction of the global intensity (i.e., efficiency) of the biological pump (Hain et al., 2014). The recorded inverse change in nutrient availability suggests a causal link. A reduced efficiency of the biological pump and associated decrease of the fraction of biomass transported out of the photic zone could have resulted in high rates of nutrient recycling in the upper part of the water column (D'Hondt, 2005). This suggests that the reduction of the biological pump strength, recorded by the benthic foraminiferal record, is a consequence of the decreased efficiency of the biological pump, recorded by the carbon isotope and dinoflagellate cyst records. The strong correlation between the bulk carbon isotope curves and the Shannon diversity index $(H)$ of the benthic foraminiferal records at both Okçular $\left(R^{2}=0.73, p<0.001\right)$ and El Kef $\left(R^{2}=0.74\right.$, $p<0.001)$ suggest a clear link between the changes in benthic foraminiferal assemblages and the collapse and recovery of biological pump efficiency.

As a result of the reduced biological pump efficiency, more nutrients remained available for the early Paleocene phytoplankton community. At Tethyan margin sites this is indi- 


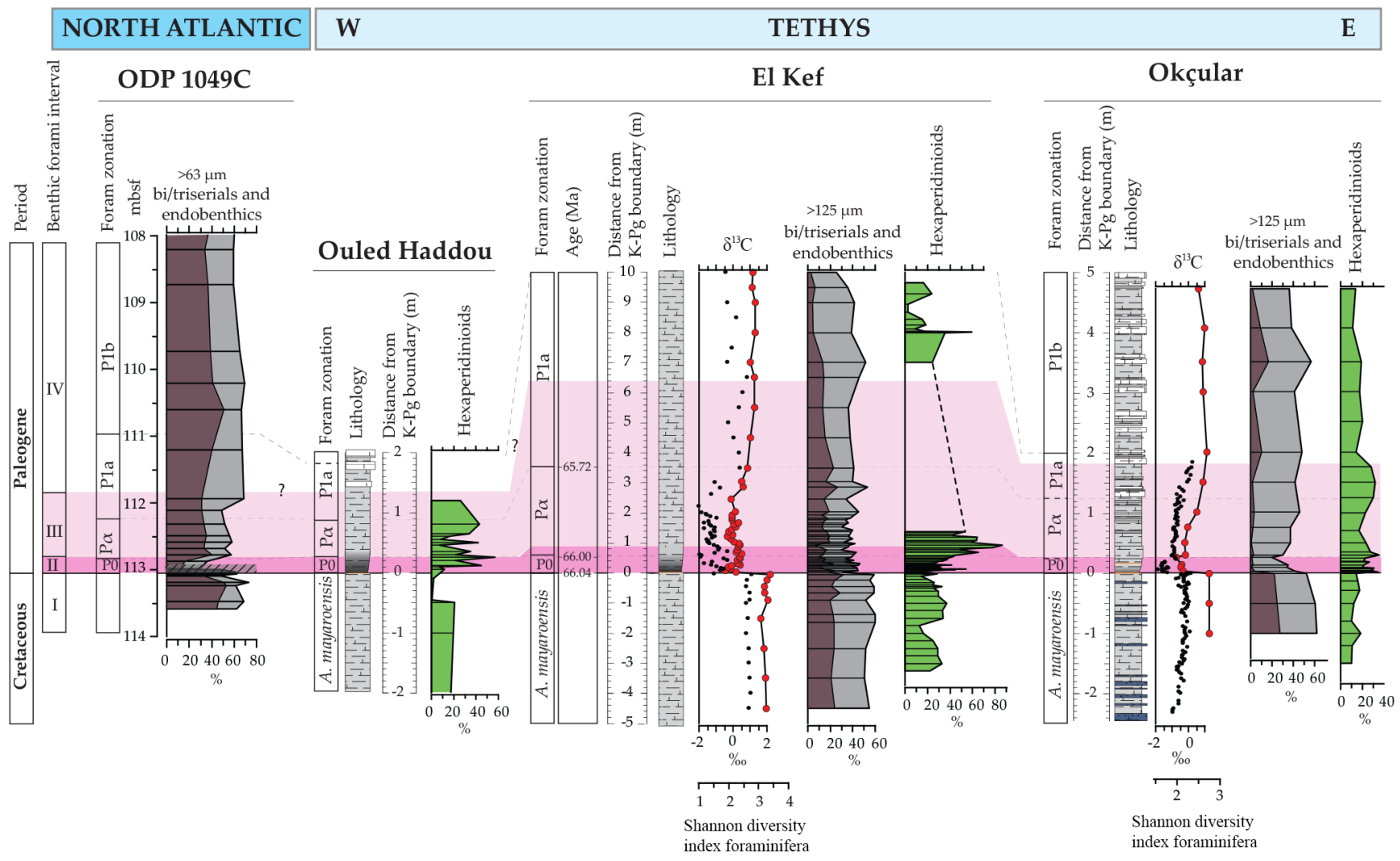

Figure 8. The benthic foraminiferal $(>125 \mu \mathrm{m})$ dinocyst and bulk stable carbon isotope records of Okçular (Turkey) and El Kef (Tunisia), the dinocyst record of Ouled Haddou (Morocco), and the benthic foraminiferal record ( $>63 \mu \mathrm{m}$ ) of ODP Hole 1049C Blake Nose (North Atlantic). Note that the definition of "hexaperidinioids" used is provided in the text. The four phases identified based on the bulk stable carbon isotopes and the Shannon diversity index $(H)$ of the benthic foraminiferal records are indicated (I-IV). The $>63 \mu \mathrm{m}$ size fraction benthic foraminiferal record of ODP Hole 1049C is from Alegret and Thomas (2004), who argued that the lowermost Paleocene of this site comprised reworked foraminifera. This interval is indicated by a dashed bar in the figure. The biostratigraphy of Ouled Haddou is from Slimani and Toufiq (2013), whereas the dinocyst record of this site is from Slimani et al. (2010). The biostratigraphy of El Kef is based on Brinkhuis et al. (1998), Speijer and van der Zwaan (1996) and Molina et al. (2006). The fine-fraction stable carbon isotope record (black dots) of El Kef is from Keller and Lindinger (1989). The Shannon diversity index (red dots), relative abundances of bi-/triserial benthic taxa (dark purple), and all endobenthic foraminifera (light purple) are based on the $>125 \mu \mathrm{m}$ size fraction foraminiferal data of Speijer and van der Zwaan (1996). The palynological data of El Kef are from Brinkhuis et al. (1998) (lower part) and Guasti et al. (2005) (upper part). The Shannon diversity index of the $>125 \mu \mathrm{m}$ size fraction benthic foraminiferal record (red dots), the relative contribution of bi-/triserial benthic taxa (dark purple), all endobenthic foraminifera (light purple), and hexaperidinioid dinocysts from Okçular are from this study. The bulk stable carbon isotope record of Okçular (black dots) is from Açikalin et al. (2015). Mbsf indicates meters below sea floor.

cated by the higher abundance of hexaperidinioids. Similarly, blooms of eutrophic survivor taxa of calcareous nanoplankton at open ocean sites have been suggested to be related to the buildup of nutrients in the open ocean photic zone (Schueth et al., 2015). Although the carbon isotope gradients between surface and deep waters indicate that the recovery of the biological pump took hundreds of thousands of years (Zachos et al., 1989; Kump, 1991; D’Hondt et al., 1998; Coxall et al., 2006; Birch et al., 2016), our records suggest that the enhanced recycling of nutrients in the Tethys was particularly intense during two phases in the first tens of thousands years after the impact (Fig. 8).

\subsubsection{Global responses}

The decrease in export productivity following the $\mathrm{K}-\mathrm{Pg}$ boundary is not only recognized in the Tethyan realm. In the Atlantic Ocean, Southern Ocean and the Indian Ocean, a decrease of the biological pump strength after the K-Pg boundary was also observed in neritic to abyssal environments (e.g., Thomas, 1990; Olsson et al., 1996; Hull et al., 2011; Alegret et al., 2012). As an example, the $>63 \mu \mathrm{m}$ size fraction benthic foraminiferal $\mathrm{K}-\mathrm{Pg}$ boundary record of Blake Nose (ODP Hole 1049C, northwestern Atlantic; Alegret and Thomas, 2004) shows a pattern that is strikingly similar to the $>125 \mu \mathrm{m}$ size fraction records in the Tethyan realm, with a strong decrease of endobenthics in Zone P0 followed by a 
gradual recovery across zones $\mathrm{P} \alpha$ and P1a (Fig. 8). The similarities between the benthic foraminiferal patterns of Tethyan outer neritic to middle bathyal $(200-1500 \mathrm{~m})$ sites and those of the middle to lower bathyal $(1500-1600 \mathrm{~m})$ record of Blake Nose (Alegret and Thomas, 2004) suggest that these records register a global decrease in export productivity following the K-Pg boundary.

However, several open ocean sites, mostly in the Pacific, show an opposite trend, with several lines of evidence suggesting an increased biological pump strength at these sites (e.g., Hull et al., 2011; Alegret et al., 2012). This led Alegret et al. (2012) to conclude that the decrease in biological pump strength after the K-Pg boundary was most likely a regional instead of a global effect, arguing against the Living Ocean hypothesis. We would argue that low-productivity open ocean sites like the central Pacific are characterized by very different ecosystem structures and higher productivity as those along the Tethyan margins (e.g., Dortch and Packerd, 1989). Therefore, the consequence of ecosystem reorganization resulting from the mass extinction was likely very different in the open ocean Pacific (e.g., Sibert et al., 2014). Esmeray-Senlet et al. (2015) proposed the term "Heterogeneous Ocean" for this conceptual model, as an alternative to the Living Ocean model. Supposedly, the Heterogeneous Ocean was characterized by a strong geographic heterogeneity in the extinction patterns and food supply to the sea floor.

However, as the primary food source for open ocean, deepsea benthic communities generally consists of refractory organic matter (e.g., Jiao et al, 2010), it remains uncertain whether changes in the intensity of recycling of the generally more labile organic matter in the surface ocean will result in changes in the amount of organic matter that benthic communities receive, as they will likely continue to receive recalcitrant organic matter at barely diminished rates despite the collapse of the biological pump.

In addition, it should be noted that, although the biological pump efficiency is generally relatively high in open ocean realms such as the central Pacific, the biological pump strength is generally very low at these sites (Honjo et al, 2008; Henson et al., 2011). Small changes in absolute biological pump strength at such a locality could therefore have had a large effect on the local oligotrophic benthic community (Alegret and Thomas, 2009), but they likely represented only a small fraction of the net amount of organic matter globally transported to the deep. Hence, even though local biological pump strength might have increased at some lowproductivity, deep-sea sites, the large decrease in biological pump strength recorded at many other sites means that the net amount of organic matter globally transported out of the surface ocean was likely still reduced in the post-impact world (Birch et al., 2016). Therefore, we argue that such Pacific records do not represent the general pattern. The global ocean response can be characterized as heterogeneous; however, the K-Pg boundary mass extinction did lead to a strong reduction of the net amount of organic matter globally trans- ported from the surface to the sea floor, while biological productivity recovered rapidly after the extinction event, in accordance with the Living Ocean hypothesis.

\subsection{Long-term recovery}

Following the disaster phase, the hexaperidinioid cysts at Okçular and El Kef decreased in abundance and the abundance of endobenthic forms increased again, as the recovery of the benthic community was initiated. This recovery phase is approximately correlative to Zone $\mathrm{P} \alpha$ and the basal part of Zone P1a, which, according to the Paleogene age constraints of Vandenberghe et al. (2012), represents at least $300 \mathrm{kyr}$. This duration is in agreement with the estimations provided by Birch et al. (2016). During this phase, the carbon isotope records remain well below pre-impact values and the diversity of the benthic foraminiferal community has not yet fully recovered (Figs. 4-8). This indicates that the rapid and short-lived K-Pg boundary disaster was followed by a relatively long recovery phase, in line with previous estimates of a multimillion-year biological recovery (e.g., Coxall et al., 2006). While the impact-related environmental perturbations were short lived (Kring, 2007; Vellekoop et al., 2014, 2016), the extinctions amongst important biological groups led to a reduction of the organic flux from the photic zone to deep water, resulting in major long-term biological and paleoceanographic reorganizations. Only with the evolutionary recovery of the pelagic community governing the biological carbon pump did export productivity start to increase again (e.g., Coxall et al., 2006; Birch et al., 2016).

\section{Conclusions}

The marine palynological, benthic foraminiferal and bulk stable isotope records of the Okçular and El Kef sections reveal major changes across the K-Pg boundary interval, portraying the biological crisis at the K-Pg boundary and subsequent recovery in the early Paleocene. Based on the succession of benthic faunal assemblages at a number of Tethyan margin sites, four phases can be recognized across the $\mathrm{K}-\mathrm{Pg}$ boundary interval: the Maastrichtian or pre-impact phase (I), a disaster phase (II), a recovery phase (III), and an early Paleocene post-recovery phase (IV).

Following the K-Pg boundary impact, some localities show a large, short-lived flux of food to the sea floor, likely related to the mass mortality at the K-Pg boundary. However, since export productivity was greatly reduced after the $\mathrm{K}-\mathrm{Pg}$ boundary mass extinction, it is likely that, after the initial post-impact influx, very little fresh organic matter reached the sea floor. This reduction of export productivity in the post-extinction disaster phase eventually resulted in a lower food supply to the sea floor. This presented a major stress factor for benthic organisms in the western Tethys. The reduced food supply resulted in an abrupt impoverishment of 
benthic communities. As the downward transport of nutrients was slowed down, recycling in upper layers increased. As a result, more nutrients remained available for the early Paleocene phytoplankton community, leading to blooms of dinoflagellates along the Tethyan margins and blooms of calcareous nanoplankton taxa in more open ocean sites. Our records show that the enhanced recycling of nutrients in the Tethys was particularly intense in the tens of thousands of years after the impact. Following this, the slow evolutionary recovery of the pelagic community governing the biological carbon pump resulted in a gradually increasing export productivity in the hundreds of thousands of years after the impact. Hence, our integration of dinocyst and benthic foraminiferal records across the $\mathrm{K}-\mathrm{Pg}$ boundary provides important new insights into the ecological responses to the reduction of export productivity following the mass extinction at the Cretaceous-Paleogene boundary, highlighting the direct ecological consequences of the Living Ocean conditions in the post-impact world.

\section{Data availability}

All data related to publication are available in the Supplement.

\section{The Supplement related to this article is available online at doi:10.5194/bg-14-885-2017-supplement.}

Author contributions. Johan Vellekoop, Lineke Woelders, and Henk Brinkhuis designed the research. Samples were collected in the field by Johan Vellekoop, Sanem Açikalin, Ismail Ö. Yilmaz, and Jan Smit. Palynological analyses were carried out by Johan Vellekoop. Benthic foraminiferal analyses were carried out by Lineke Woelders and Robert P. Speijer. Johan Vellekoop, Lineke Woelders, and Bas van de Schootbrugge prepared the manuscript with input from all authors.

Competing interests. The authors declare that they have no conflict of interest.

Acknowledgements. This work was supported by the Netherlands Organization for Scientific Research (NWO) Open Competition Grant ALWPJ/09047 to H. Brinkhuis and the Research Foundation Flanders (FWO) grant G.0B85.13 to R. P. Speijer. We thank L. Kump, F. Boscolo Galazzo, P. Roopnarine and one anonymous referee for their suggestions.

Edited by: D. Gillikin

Reviewed by: L. Kump, F. Boscolo Galazzo, and P. Roopnarine

\section{References}

Açikalin, S., Vellekoop, J., Ocakoğlu, F., Y1lmaz, I. Ö., Smit, J., Altiner, S. O., Goderis, S., Vonhof, H., Speijer, R. P., Woelders, L., Fornaciari, E., and Brinkhuis, H.: Geochemical and paleontological characterization of a new K-Pg Boundary locality from the Northern branch of the Neo-Tethys: MudurnuGöynük Basin, NW Turkey, Cretaceous Res., 52, 251-267, doi:10.1016/j.cretres.2014.07.011, 2015.

Alegret, L. and Thomas, E.: Food supply to the seafloor in the Pacific Ocean after the Cretaceous/Paleogene boundary event, Mar. Micropaleontol., 73, 105-116, 2009.

Alegret, L., Molina, E., and Thomas, E.: Benthic foraminiferal turnover across the Cretaceous/Paleogene boundary at Agost (southeastern Spain): paleoenvironmental inferences, Mar. Micropaleontol., 48, 251-279, 2003.

Alegret, L., Thomas, E., and Lohmann, K. C.: End-Cretaceous marine mass extinction not caused by productivity collapse, P. Natl. Acad. Sci. USA, 109, 728-732, doi:10.1073/pnas.1110601109, 2012.

Alegret, L., Rodríguez-Tovar, F. J., and Uchman, A.: How bioturbation obscured the Cretaceous-Paleogene boundary record, Terra Nova, 27, 225-230, doi:10.1111/ter.12151, 2015.

Altiner, D., Koçyiğit, A., Farinacci, A., Nicosia, U., and Conti, M. A.: Jurassic-Lower Cretaceous stratigraphy and paleogeographic evolution of the southern part of north-western Anatolia (Turkey), Geologica Romana, 27, 13-80, 1991.

Alvarez, L.W., Alvarez, W., Asaro, F., and Michel, H. V.: Extraterrestrial cause for the Cretaceous-Tertiary extinction, Science, 208, 1095-1108, 1980.

Alegret, L. and Thomas, E.: Benthic foraminifera and environmental turnover across the Cretaceous/Paleogene boundary at Blake Nose (ODP Hole 1049C, Northwestern Atlantic), Palaeogeogr. Palaeocl., 208, 59-83, doi:10.1016/j.palaeo.2004.02.028, 2004.

Armstrong, R. A., Lee, C., Hedges, J. I., Honjo, S., and Wakeham, S. G.: A new mechanistic model for organic carbon fluxes in the ocean based on the quantitative association of POC with ballast materials, Deep-Sea Res. Pt. II, 49, 219-236, 2002.

Aubert, J. and Berggren, W. A.: Paleocene benthic foraminiferal biostratigraphy and paleoecology of Tunisia, Bull. du Cent. de Rech. de Pau - SNPA, 10, 379-469, 1976.

Berggren, W. A. and Aubert, J.: Paleocene benthonic foraminiferal biostratigraphy, paleobiogeography and paleoecology of Atlantic-Tethyan regions: midway-type fauna, Palaeogeogr. Palaeocl., 18, 73-192, 1975.

Bernaola, G. and Monechi, S.: Calcareous nannofossil extinction and survivorship across the Cretaceous-Paleogene boundary at Walvis Ridge (ODP Hole 1262C, South Atlantic Ocean), Palaeogeogr. Palaeocl., 255, 132-156, doi:10.1016/j.palaeo.2007.02.045, 2007.

Bernhard, J. M.: Characteristic assemblages and morphologies of benthic foraminifera from anoxic, organic-rich deposits: Jurassic through Holocene, J. Foramin. Res., 16, 207-215, 1986.

Birch, H. S., Coxall, H. K., Pearson, P. N., Kroon, D., and Schmidt, D. N.: Partial collapse of the marine carbon pump after the Cretaceous-Paleogene boundary, Geology, 44, 287-290, doi:10.1130/G37581.1, 2016.

Brinkhuis, H. and Zachariasse, W. J.: Dinoflagellate cysts, sea level changes and planktonic foraminifers across the Cretaceous- 
Tertiary boundary at El Haria, northwest Tunisia, Mar. Micropaleontol., 13, 153-191, 1988,

Brinkhuis, H., Bujak, J. P., Smit, J., Versteegh, G. J. M., and Visscher, H.: Dinoflagellate-based sea surface temperature reconstructions across the Cretaceous-Tertiary boundary, Palaeogeogr. Palaeocl., 141, 67-83, 1998

Buesseler, K. O.: The decoupling of production and particulate export in the surface ocean, Global Biogeochem. Cy., 12, 297-310, 1998.

Buzas, M. A., Culver, S. J., and Jorissen, F. J.: A statistical evaluation of the microhabitats of living (stained) infaunal benthic foraminifera, Mar. Micropaleontol., 20, 311-320, doi:10.1016/0377-8398(93)90040-5, 1993.

Coccioni, R. and Galeotti, S.: K-T boundary extinction: geologically instantaneous or gradual event? Evidence from deep-sea benthic foraminifera, Geology, 22, 779-782, 1994.

Corliss, B. H.: Microhabitats of benthic foraminifera within deepsea sediments, Nature, 314, 435-438, doi:10.1038/314435a0, 1985.

Corliss, B. H. and Chen, C.: Morphotype patterns of Norwegian Sea deep-sea benthic foraminifera and ecological implications, Geology, 16, 716-719, doi:10.1130/00917613(1988)016<0716:MPONSD>2.3.CO;2 1988.

Coxall, H. K., D'Hondt, S., and Zachos, J. C.: Pelagic evolution and environmental recovery after the Cretaceous-Paleogene mass extinction, Geology, 34, 297-300, doi:10.1130/G21702.1, 2006.

Culver, S. J.: Benthic foraminifera across the Cretaceous-Tertiary (K-T) boundary: a review, Mar. Micropaleontol., 47, 177-226, 2003.

Cushman, J. A.: Upper Cretaceous foraminifera of the Gulf coastal region of the United States and adjacent areas, US Geolog. Surv., Prof. Pap., 206, 241 pp., 1946.

Cushman J. A.: Paleocene foraminifera of the Gulf Coastal Region of the United States and adjacent regions, US Geol. Surv., Prof. Pap., 232, 75 pp., 1951.

D'Hondt, S.: Consequences of the Cretaceous/Paleogene Mass Extinction for Marine Ecosystems, Annu. Rev. Ecol. Evol. S., 36, 295-317, doi:10.1146/annurev.ecolsys.35.021103.105715, 2005.

D'Hondt, S. and Zachos, J. C.: Cretaceous foraminifera and the evolutionary history of planktic photosymbiosis, Paleobiology, 24, 512-523, 1998,

D'Hondt, S., Donaghay, P., Zachos, J. C., Luttenberg, D., and Lindinger, M.: Organic Carbon Fluxes and Ecological Recovery from the Cretaceous-Tertiary Mass Extinction, Science, 282, 276-279, 1998.

Donze, P., Colin, J.-P., Damotte, R., Oertli, H.J., Peypouquet, J.-P., and Said, R.: Les ostracodes du Campanien terminal à l'Eocène inférieur de la coupe du Kef, Tunésie nord-occidentale, Bull. des Centr. Recher. Expl.-Prod. Elf Aquit., 6, 273-335, 1982.

Dortch, Q. and Packard, T. T.: Differences in biomass structure between oligotrophic and eutrophic marine ecosystems, Deep-Sea Res., 36, 223-240, 1989.

Ernst, S. R., Guasti, E., Dupuis, C., and Speijer, R. P.: Environmental perturbation in the southern Tethys across the Paleocene/Eocene boundary (Dababiya, Egypt): Foraminiferal and clay mineral records, Mar. Micropaleontol., 60, 89-111, doi:10.1016/j.marmicro.2006.03.002, 2006
Eshet, Y., Moshkovitz, S., Habib, D., Benjamini, C., and Magaritz, M.: Calcareous nannofossil and dinoflagellate stratigraphy across the Cretaceous/Tertiary boundary at Hor Hahar, Israel, Mar. Micropaleontol., 18, 199-228, 1992.

Eshet, Y., Almogi-Labin, A., and Bein, A.: Dinoflagellate cysts, paleoproductivity and upwelling systems: A Late Cretaceous example from Israel, Mar. Micropaleontol., 23, 231-240, 1994.

Esmeray-Senlet, S., Wright, J. D., Olsson, R. K., Miller, K. G., Browning, J. V., and Quan, T. M.: Evidence for reduced export productivity following the Cretaceous/Paleogene mass extinction, Paleoceanography, 30, 718-738, doi:10.1002/2014PA002724, 2015.

Giusberti, L., Boscolo Galazzo, F., and Thomas, E.: Variability in climate and productivity during the Paleocene-Eocene Thermal Maximum in the western Tethys (Forada section), Clim. Past, 12, 213-240, doi:10.5194/cp-12-213-2016, 2016.

Guasti, E., Kouwenhoven, T. J., Brinkhuis, H., and Speijer, R. P.: Paleocene sea-level and productivity changes at the southern Tethyan margin (El Kef, Tunisia), Mar. Micropaleontol., 55, 1$17,2005$.

Habib, D. and Saeedi, F.: The Manumiella seelandica global spike: Cooling during regression at the close of the Maastrichtian, Palaeogeogr. Palaeocl., 255, 87-97, 2007.

Hain, M. P., Sigmal, D. M., and Haug, G. H.: 8.18 - The biological Pump in the Past, in: Reference Module in Earth Systems and Environmental Sciences, Treatise on Geochemistry (Second Edition), The Oceans and Marine Geochemistry, 8, 485-517, doi:10.1016/B978-0-08-095975-7.00618-5, 2014.

Hayek, L. C. and Buzas, M. A.: On the proper and efficient use of diversity measures with individual field samples, J. Foramin. Res., 43, 305-313, 2013.

Henson, S. A., Sanders, R., Madsen, E., Morris, P. J., Le Moigne, F., and Quartly, G. D.: A reduced estimate of the strength of the ocean's biological carbon pump, Geophys. Res. Lett., 38, L04606, doi:10.1029/2011GL046735, 2011.

Hilting, A. K., Kump, L. R., and Bralower, T. J.: Variations in the oceanic vertical carbon isotope gradient and their implications for the Paleocene-Eocene biological pump, Paleoceanography, 23, PA3222, doi:10.1029/2007PA001458, 2008

Honjo, S., Manganini, S. J., Krishfield, R. A., and Francois, R.: Particulate organic carbon fluxes to the ocean interior and factors controlling the biological pump: A synthesis of global sediment trap progams since 1983, Prog. Oceanogr., 76, 217-285, doi:10.1016/j.pocean.2007.11.003, 2008.

Huber, B. T., MacLeod, K. G., and Norris, R. D.: Abrupt extinction and subsequent reworking of Cretaceous planktonic foraminifera across the Cretaceous-Tertiary boundary: Evidence from the subtropical North Atlantic, in: Catastrophic Events and Mass Extinctions: Impacts and Beyond, edited by: Koeberl, C. and MacLeod, K. G., Geol. S. Am. S., 356, 277-289, Boulder, Colorado, USA, 2002.

Hull, P. M., Norris, R. D., Bralower, T. J., and Schueth, J. D.: A role for chance in marine recovery from the end-Cretaceous extinction, Nat. Geosci., 4, 856-860, doi:10.1038/ngeo1302, 2011.

Hsü, K. J. and McKenzie, J. A.: A "Strangelove" ocean in the earliest Tertiary, in: Natural variations Archean to present, edited by: Sundquist, E. T. and Broecker, W. S., The carbon cycle and atmospheric $\mathrm{CO}_{2}$, American Geophysical Union, Washington, D.C., USA, 487-492, 1985. 
Jiao, N., Herndl, G. J., Hansell, D. A., Benner, R., Kattner, G., Wilhelm, S. W., Kirchman, D. L., Weinbauer, M. G. Luo, T., Chen, F., and Azam, F.: Microbial production of recalcitrant dissolved organic matter: long-term carbon storage in the global ocean, Nat. Rev., 8, 593-599, doi:10.1038/nrmicro2386, 2010.

Jorissen, F. J., de Stigter, H. C., and Widmark, J. G. V.: A conceptual model explaining benthic foraminiferal microhabitats, Mar. Micropaleontol., 26, 3-15, doi:10.1016/0377-8398(95)00047-X, 1995.

Jorissen, F. J., Fontanier, C., and Thomas, E.: Paleoceanographical proxies based on deep-sea benthic foraminiferal assemblage characteristics, in: Proxies in Late Cenozoic Paleoceanography: Pt. 2: Biological tracers and biomarkers, edited by: HillaireMarcel, C. and de Vernal, A., 263-326, Elsevier, Amsterdam, the Netherlands, 2007

Kaiho, K., Kajiwara, Y., Tazaki, K., Ueshima, M., Takeda, N., Kawahata, H., Arinobu, T., Ishiwatari, R., Hirai, A., and Lamolda, M. A.: Oceanic primary productivity and dissolved oxygen levels at the Cretaceous/Tertiary boundary: their decrease, subsequent warming and recovery, Paleoceanography, 14, 511-524, 1999.

Keller, G. and Lindinger, M.: Stable isotope, TOC and $\mathrm{CaCO}_{3}$ record across the Cretaceous/Tertiary boundary at El Kef, Tunisia, Palaeogeogr. Palaeocl., 73, 243-265, 1989.

Kellough, G. R.: Paleoecology of the Foraminiferida of the Wills Point Formation (Midway Group) in northeast Texas, Trans. Gulf Coast Assoc. Geol. Soc., 15, 73-153, 1965.

Kring, D. A.: The Chicxulub impact event and its environmental consequences at the Cretaceous-Tertiary boundary, Palaeogeogr. Palaeocl., 255, 4-21, 2007.

Kump, L. R.: Interpreting carbon-isotope excursions: Strangelove oceans, Geology, 19, 299-302, 1991.

Machalski, M., Vellekoop, J., Dubicka, Z., Peryt, D., and Harasimiuk, M.: Late Maastrichtian cephalopods, dinoflagellate cysts and foraminifera from the Cretaceous-Paleogene succession at Lechówka, southeast Poland: Stratigraphic and environmental implications, Cretaceous Res., 57, 208-227, doi:10.1016/j.cretres.2015.08.012, 2016.

Molina, E.: Evidence and causes of the main extinction events in the Paleogene based on extinction and survival patterns of foraminifera, Earth-Sci. Rev., 140, 166-181, doi:10.1016/j.earscirev.2014.11.008, 2015.

Molina, E., Alegret, L., Arenillas, I., and Arz., J.: The Global Boundary Stratotype Section and Point for the base of the Danian Stage (Paleocene, Paleogene,“ Tertiary”, Cenozoic) at El Kef, Tunisia-Original definition and revision, Episodes, 29, 263 273, 2006.

Olsson, R. K., Liu, C., and van Fossen, M.: The Cretaceous-Tertiary catastrophic event at Millers Ferry, Alabama, in: The CretaceousTertiary Event and Other Catastrophes in Earth History, edited by: Ryder, G., Fastovsky, D., and Gartner, S., Geol. S. Am. S., 307, 263-277, 1996.

Peryt, D.: Benthic foraminiferal response to the CenomanianTuronian and Cretaceous-Paleogene boundary events, Przegląd Geol., 52, 827-832, 2004.

Peryt, D., Alegret, L., and Molina, E.: The Cretaceous/Palaeogene (K/P) boundary at Aïn Settara, Tunisia: restructuring of benthic foraminiferal assemblages, Terra Nova, 14, 101-107, 2002.
Ramette, A.: Multivariate analyses in microbial ecology, FEMS Microbiol. Ecol., 62, 142-160, 2007.

Rodríguez-Tovar, F. J., Uchman, A., M'Hamdi, A., Riahi, S., and Ismail-Lattrache, K. B.: Ichnological record of palaeoenvironment from the Cretaceous-Paleogene boundary interval at El Kef, Tunisia: The first study of old and new sections at the stratotype area, J. Afr. Earth Sci., 120, 23-30, doi:10.1016/j.jafrearsci.2016.04.017, 2016.

Saner, S.: Mudurnu-Göynük Havzasının Jura ve Sonrasıçökelim nitelikleriyle paleocoğrafya yorumlaması, TJK Bülteni, 23, 3952, 1980.

Schiøler, P., Brinkhuis, H., Roncaglia, L., and Wilson, G. J.: Dinoflagellate biostratigraphy and sequence stratigraphy of the Type Maastrichtian (Upper Cretaceous), ENCI Quarry, The Netherlands, Mar. Micropaleontol., 31, 65-95, 1997.

Schueth, J. D., Bralower, T. J., Jiang, S., and Patzkowsky M. E.: The role of regional survivor incumbency in the evolutionary recovery of calcareous nannoplankton from the Cretaceous/Paleogene (K/Pg) mass extinction, Paleobiology, 41, 661679, doi:10.1017/pab.2015.28, 2015.

Scotese, C. R.: A continental drift flipbook, J. Geology, 112, 729741, 2004.

Scotese, C. R. and Dreher, C.: GlobalGeology, available at: http: /www.GlobalGeology.com (last access: 11 March 2014), 2012.

Sepkoski, J. J.: Patterns of Phanerozoic extinction: a perspective from global data bases, in: Global Events and Event Stratigraphy, edited by: Walliser, O. H., Springer, Berlin, Germany, 3552,2016

Sibert, E. C., Hull, P. M., and Norris, R. D.: Resilience of Pacific pelagic fish across the Cretaceous/Palaeogene mass extinction, Nat. Geosci., 7, 667-670, doi:10.1038/NGEO2227, 2014.

Slimani, H. and Toufiq, A.: A Cretaceous-Paleogene boundary geological site, revealed by planktic foraminifera and dinoflagellate cysts, at Ouled Haddou, eastern external Rif Chain, Morocco, J. Afr. Earth Sci., 88, 38-52, doi:10.1016/j.jafrearsci.2013.08.008, 2013.

Slimani, H., Louwye, S., and Toufiq, A.: Dinoflagellate cysts form the Cretaceous-Paleogene boundary at Ouled Haddou, southeastern Rif, Morocco: biostratigraphy, paleoenvironments and paleobiogeography, Palynology, 34, 90-124, doi:10.1080/01916121003629933, 2010.

Sluijs, A. and Brinkhuis, H.: A dynamic climate and ecosystem state during the Paleocene-Eocene Thermal Maximum: inferences from dinoflagellate cyst assemblages on the New Jersey Shelf, Biogeosciences, 6, 1755-1781, doi:10.5194/bg-6-17552009, 2009.

Smit, J.: Extinction and evolution of planktonic foraminifera after a major impact at the Cretaceous/Tertiary boundary, Geol. S. Am. S., 190, 329-352, 1982.

Smit, J. and Romein, A. J. T.: A sequence of events across the Cretaceous-Tertiary boundary, Earth Planet. Sci. Lett., 74, 155170, 1985.

Speijer, R. P: Extinction and recovery patterns in benthic foraminiferal paleocommunities across the Cretaceous/Paleogene and Paleocene/Eocene boundaries, Geologica Ultraiectina, 124, Faculteit Aardwetenschappen, PhD Thesis, Universiteit Utrecht, Utrecht, the Netherlands, 1994.

Speijer, R. P. and van Der Zwaan, G. J.: Extinction and survivorship of southern Tethyan benthic foraminifera across the Cre- 
taceous/Paleogene boundary, in: Biotic recovery from mass extinction events, edited by: Hart, M. B., Geolog. Soc. Spec. Publ., London, UK, 102, 343-371, 1996.

Stemmann, L. and Boss, E.: Plankton and Particle Size and Packaging: From Determining Optical Properties to Driving the Biological Pump, Annu. Rev. Mar. Sci., 4, 263-290, doi:10.1146/annurev-marine-120710-100853, 2012.

Thomas, E.: Late Cretaceous-early Eocene mass extinctions in the deep sea, Geol. S. Am. S., 247, 481-495, 1990.

Vandenberghe, N., Hilgen, F. J., and Speijer, R. P.: The Paleogene Period, in: The Geologic Time Scale 2012, edited by: Gradstein, F. M., Ogg, J. G., Schmitz, M. D. and Ogg, G. M., 2, 855-921, Elsevier, Boston, USA, 2012.

Vellekoop, J., Sluijs, A., Smit, J., Schouten, S., Weijers, J. W. H., Sinninghe Damsté, J. S., and Brinkhuis, H.: Rapid shortterm cooling following the Chicxulub impact at the CretaceousPaleogene boundary, P. Natl. Acad. Sci. USA, 111, 7537-7541, doi:10.1073/pnas.1319253111, 2014.
Vellekoop, J., Smit, J., van de Schootbrugge, B., Weijers, J. W. H., Galeotti, S., Sinninghe Damsté, J. S., and Brinkhuis, H.: Palynological evidence for prolonged cooling along the Tunisian continental shelf following the K-Pg boundary impact, Palaeogeogr. Palaeocl., 426, 216-228, doi:10.1016/j.palaeo.2015.03.021, 2015.

Vellekoop, J., Esmeray-Senlet, S., Miller, K. G., Browning, J. V., Sluijs, A., van de Schootbrugge, B., Sinninghe Damsté, J. S., and Brinkhuis, H.: Evidence for Cretaceous-Paleogene boundary bolide "impact winter" conditions from New Jersey, USA, Geology, 44, 619-622, doi:10.1130/G37961.1, 2016

Woelders, L. and Speijer, R.: Stable seafloor conditions, sea level and food supply during the latest Maastrichtian at Brazos River, Texas, Mar. Micropaleontol., 121, 41-51, doi:10.1016/j.marmicro.2015.10.002, 2015.

Zachos, J. C., Arthur, M. A., and Dean, W. E.: Geochemical evidence for suppression of pelagic marine productivity at the Cretaceous/Tertiary boundary, Nature, 337, 61-64, 1989. 